
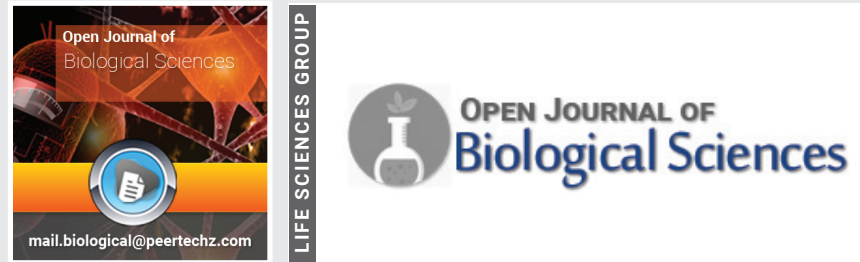

\title{
Clinical potential in modern medicine of fibrin glues as drug delivery system
}

\author{
João Paulo Galletti Pilon', Daniela Vieira Buchaim ${ }^{1,2}$, \\ Abdul Latif Hamzé3 ${ }^{3}$ Carlos Henrique Bertoni Reis', Getúlio \\ Duarte Júnior ${ }^{1}$, Karina Torres Pomini ${ }^{4}$ and Rogério Leone \\ Buchaim ${ }^{1,4 *}$ \\ 1Postgraduate Program in Structural and Functional Interactions in Rehabilitation, University of Marilia \\ (UNIMAR), Marília (SP) 17525-902, Brazil \\ ${ }^{2}$ Medical School, University Center of Adamantina (UniFAI), 17800-000, Adamantina, Brazil \\ ${ }^{3}$ Medical School, University of Marilia (UNIMAR), Marília (SP) 17525-902, Brazil \\ ${ }^{4}$ Department of Biological Sciences (Anatomy), Bauru School of Dentistry, University of São Paulo \\ (USP), 17012-901, Bauru, Brazil
}

Received: 16 December, 2019
Accepted: 05 February, 2020

Published: 07 February, 2020

*Corresponding author: Rogério Leone Buchaim, Department of Biological Sciences, Bauru School of Dentistry, University of São Paulo (USP), Alameda Dr. Octávio Pinheiro Brisola 9-75, Vila Nova Cidade Universitária, 17012-901, Bauru, São Paulo, Brazil,

E-mail: rogerio@fob.usp.br

https://www.peertechz.com

Check for updates

\section{Short communication}

In an attempt to achieve greater therapeutic efficiency of products, especially in the pharmacological area such as drugs in general, the drug delivery system that controls the distribution of substances through macromolecular carriers has been developed with the primary objective of optimizing their delivery to target locations [1].

Records in the scientific literature of pioneering controlled drug delivery studies date back to the 1960s at Harvard with the in vivo implantation of a silicone tube that became a drug delivery device, in this case anesthetic gases, at a constant rate of release. [2]. Clinical use was approved in the 1980 s and 1990s with the use of microscopic degradable polymer depot Drug Delivery Systems (DDS) but it can be cited that clinical success occurred in the 2000s with nanoscopic products [3]. From this period a rapid evolution occurred and the range of use at both molecular and supramolecular levels was expanded [4]. The clinical use of nanotechnology in health has been a major revolution, with controlled drug release being one of its examples in treating various types of cancer, manufacturing vaccines and treating fungal infections using liposomes as a component [5].
Among the various products used as DDS, we can highlight nanogels and fibrin sealants. Nanogels are made up of hydrogel and nanoparticles and stand out for their biological consistency, stability and carrying capacity [6]. Fibrin sealants, which were originally used as hemostatics, have over time diversified their use, mainly due to their biocompatibility property, threedimensional structure and degradation time, leading to the possibility of use as DDS [7]. In Europe, commercial sales of fibrin sealants began in the late 1970s, while in the United States in 1998, one of the world's most marketed products, Tisseel ${ }^{\circledR}$, was distributed by Baxter Healthcare Corporation (Glendale, CA) [8]. Fibrin sealants are the only agents currently approved with sealant, hemostatic and adhesive properties by the Food and Drug Administration (FDA) [9].

Initial studies with the use of fibrin sealant, at the time called fibrin glue, such as DDS date from the 80's with the mixture with antibiotics to treat mycotic aneurysms in bacterial endocarditis [10] and in the 1990s as an assistant in heart valve surgeries at the suture site, also to prevent bacterial endocarditis [11]. The composition of fibrin sealants generally contains fibrinogen and thrombin, autologous or homologous human blood plasma derivatives [9]. However, in the case of the homologous sealant, scientific research reports the risks of spreading infectious diseases such as acquired human 
immunodeficiency syndrome (SIDA), human parvovirus and hepatitis [12].

A new fibrin sealant, currently called fibrin biopolymer due to its diversity of applications and properties, was developed in Brazil by a group of researchers from CEVAP (Center of the Studies of Venoms and Venomous Animals - UNESP Botucatu, SP) without the presence of human blood. This bioproduct has been shown to be effective in a variety of preclinical and clinical situations with therapeutic potential such as repair of nerve damage [13-18], correction of bone defects [8,19-21], treatment of venous ulcers [22] and stem cell scaffolds [23].

In conclusion, several future researches to expand the use of fibrin glues as scaffolds and drug delivery systems will certainly be carried out, in several areas of medicine and other health areas, beyond their initial objective, of simple use as therapeutic glues [24].

\section{References}

1. Zylberberg C, Matosevic S (2016) Pharmaceutical liposomal drug delivery: review of new delivery systems and a look at the regulatory landscape. Drug Deliv 23: 3319-3329. Link: http://bit.ly/3bisWgq

2. Giddings CJ, Manwaring WA, Myers MN (1966) Silicone Diffusion Useful Anesthesia. Sci 154: 146-148. Link: http://bit.ly/3bhBPa1

3. Hoffman AS (2008) The origins and evolution of "controlled" drug delivery systems. J Control Release 132: 153-163. Link: http://bit.ly/2SnHUta

4. Webber MJ, Langer R (2017) Drug delivery by supramolecular design. Chem Soc Rev 46: 6600-6620. Link: http://bit.ly/372damB

5. Sanvicens N, Marco MP (2008) Multifunctional nanoparticles-properties and prospects for their use in human medicine. Trends Biotechnol 26: 425-433. Link: http://bit.ly/2tBOpQF

6. Zhang H, Zhai $Y$, Wang J, Zhai G (2016) New progress and prospects: The application of nanogel in drug delivery. Mater Sci Eng C Mater Biol Appl 60: 560-568. Link: http://bit.ly/2HOWQbd

7. Ahmad E, Fatima MT, Hoque M, Owais M, Saleemuddin M (2015) Fibrin matrices: The versatile therapeutic delivery systems. Int J Biol Macromol 81 : 121-136. Link: http://bit.ly/2GZzkv5

8. Pomini KT, Buchaim DV, Andreo JC, Rosso MPO, Della Coletta BB, et al. (2019) Fibrin sealant derived from human plasma as a scaffold for bone grafts associated with photobiomodulation therapy. Int J Mol Sci 20pii: E1761. Link: http://bit.ly/2vgkWfl

9. Spotnitz WD (2014) Fibrin Sealant: The Only Approved Hemostat, Sealant, and Adhesive-a Laboratory and Clinical Perspective. ISRN Surg 2014: 203943 Link: http://bit.ly/2vglFNB

10. Deyerling W, Haverich A, Potel J, Hetzer R (1984) A suspension of fibrin glue and antibiotic for local treatment of mycotic aneurysms in endocarditis An experimental study. Thorac Cardiovasc Surg 32: 369-372. Link: http://bit.ly/2UxhzeT

11. Karck M, Siclari E, Wahlig H, Sperling U, Schmid C, et al. (1990) Pretreatment of prosthetic valve sewing-ring with the antibiotic/fibrin sealant compound as a prophylactic tool against prosthetic valve endocarditis. Eur J Cardio-thoracic Surg 4: 142-146. Link: http://bit.ly/3862WTr

12. Ferreira RS, de Barros LC, Abbade LPF, Barraviera SRCS, Silvares MRC, et al (2017) Heterologous fibrin sealant derived from snake venom: From bench to bedside - an overview. J Venom Anim Toxins Incl Trop Dis 23: 1-12. Link: http://bit.ly/2v8MUtA

13. Buchaim DV, Cassaro CV, Shindo JVTC, Coletta BBD, Pomini KT, et al. (2019) Unique hetetologous fibrin biopolymer with hemostatic, adhesive, sealant, scaffold and drug delivery properties - a systematic review. J Venom Anim Toxins incl Trop Dis 25: 1-15. Link: http://bit.ly/37686xq

14. Rosso MPDO, Rosa Júnior GM, Buchaim DV, German IJS, Pomini KT et al. (2017) Stimulation of morphofunctional repair of the facial nerve with photobiomodulation, using the end-to-side technique or a new heterologous fibrin sealant. J Photochem Photobiol B Biol 175: 20-28. Link: http://bit.ly/377n1Yu

15. Buchaim DV, Andreo JC, Ferreira Junior RS, Barraviera B, Rodrigues AC et al. (2017) Efficacy of Laser Photobiomodulation on Morphological and Functional Repair of the Facial Nerve. Photomed Laser Surg 35: 442-449. Link: http://bit.ly/2H4kRyi

16. Buchaim DV, Rodrigues AC, Buchaim RL, Barraviera B, Junior RS, et al. (2016) The new heterologous fibrin sealant in combination with low-level lase therapy (LLLT) in the repair of the buccal branch of the facial nerve. Lasers Med Sci 31: 965-972. Link: http://bit.ly/37bHnjq

17. Buchaim RL, Andreo JC, Barraviera B, Ferreira Junior RS, Buchaim DV, et al (2015) Effect of low-level laser therapy (LLLT) on peripheral nerve regeneration using fibrin glue derived from snake venom. Injury 46: 655-660. Link: http://bit.ly/2SonrEy

18. Rosso MPO, Buchaim DV, Kawano N, Furlanette G, Pomini KT, et al. (2018) Photobiomodulation therapy (PBMT) in peripheral nerve regeneration: $A$ systematic review. Bioengineering 5: pii: E44. Link: http://bit.ly/2H1XW6D

19. de Oliveira Gonçalves JB, Buchaim DV, de Souza Bueno CR, Pomini KT, Barraviera B, et al. (2016) Effects of low-level laser therapy on autogenous bone graft stabilized with a new heterologous fibrin sealant. J Photochem Photobiol B Biol 162: 663-668. Link: http://bit.ly/2vYfONt

20. Machado EG, Issa JP, Figueiredo FA, Santos GR, Galdeano EA, et al. (2015) A new heterologous fibrin sealant as scaffold to recombinant human bone morphogenetic protein-2 (rhBMP-2) and natural latex proteins for the repair of tibial bone defects. Acta Histochem 117: 288-296. Link: http://bit.ly/2H4ICHE

21. Pomini KT, Buchaim DV, Shindo JVTC, Flato UAP, Rosso MPO, et al. (2019) Applicability of Homologous Fibrin Sealant in Bone Repair: An integrative Review. IJAERS 6: 16-23. Link: http://bit.ly/377NB3s

22. Barros LC, Ferreira RS, Barraviera SR, Stolf HO, Thomazini-Santos IA, et al. (2009) A new fibrin sealant from crotalus durissus terrificus venom: Applications in medicine. J Toxicol Environ Heal B Crit Rev 12: 553-571. Link: http://bit.ly/3blsP3E

23. Gasparotto VP, Landim-Alvarenga FC, Oliveira AL, Simões GF, Lima-Neto JF, et al. (2014) A new fibrin sealant as a three-dimensional scaffold candidate for mesenchymal stem cells. Stem Cell Res Ther 5: 78. Link: http://bit.ly/3971twu

24. Buchaim RL, Buchaim D (2017) Translational Medicine in Tissue Regeneration Open J Biol Sci 2: 002-003. Link: http://bit.ly/20BdH8C

Copyright: @ 2020 Galletti Pilon JP, et al. This is an open-access article distributed under the terms of the Creative Commons Attribution License, which permits unrestricted use, distribution, and r eproduction in any medium, provided the original author and source are credited. 